\title{
Failure of laboratory and radiological studies to predict jejunal mucosal atrophy
}

\author{
MARY C. SANDERSON, L. R. DAVIS, and ALEX P. MOWAT \\ From the Department of Child Health and Paediatric Pathology, King's College Hospital and Medical School, \\ London
}

\begin{abstract}
Sanderson, M. C., Davis, L. R., and Mowat, A. P. (1975). Archives of Disease in Childhood, 50, 526. Failure of laboratory and radiological studies to predict jejunal mucosal atrophy. Of 58 children with suspected malabsorption, 27 were shown to have subtotal or partial villous atrophy, and 31 had normal mucosal histology. Oral glucose tolerance tests, faecal fat excretion, D-xylose excretion tests, Prosparol absorption studies, haematological investigations, and radiological examination of the small bowel failed to distinguish these two groups and frequently gave misleading results. It is concluded that in suspected coeliac disease small intestinal biopsy should be performed as a primary investigation.
\end{abstract}

The paediatrician will have little difficulty with the clinical recognition of children with relatively advanced coeliac disease and can rely on laboratory investigation to show clearly the presence of malabsorption and its nutritional sequelae in these patients. A major problem, however, in clinical paediatrics is the detection of less florid malabsorption states in their early stages when gastrointestinal features and growth retardation are minimal. The practice in many paediatric departments is to employ a number of preliminary investigations in all cases of suspected coeliac disease before undertaking small intestinal biopsy. Visakorpi, Kuitunen, and Pelkonen (1970) found that the application of multiple tests for malabsorption increased their reliability, but Anderson, Gracey, and Burke (1972) have stressed some of the limitations involved and feel that multiple tests are not necessary. It is certain that these investigations are mostly unpleasant for the child and usually require hospitalization for 7 to 14 days. Since intestinal biopsy is mandatory for the diagnosis of coeliac disease, the use of tests may only be justified if they reliably predict the normality of the intestinal mucosa and thereby avoid biopsy in some cases, with its discomfort and possible complications (Townley and Barnes, 1973). We report here data obtained on a group of such children investigated in a unit similar to many general paediatric departments in this country, where special meta-

Received 16 December 1974. bolic facilities are not available and nursing time is limited. These data are compared with the results of small intestinal biopsy in order to assess the value of the preliminary investigations.

\section{Materials and methods}

Patients. During a 3-year period (October 1970September 1973) 58 infants and children were investigated, and all had small intestinal biopsies. Sweat electrolytes were normal in all. The cases were allocated to two groups according to the small bowel histology. Group 1, normal histology, 31 cases; group II, abnormal histology, 27 cases. In group II there were 22 cases with subtotal villous atrophy and 5 with partial villous atrophy. The term coeliac disease has to be avoided as a few of the cases with abnormal histology may prove to be postinfective malabsorption. These are young infants who have not yet had a gluten challenge. All cases, however, have responded to gluten-free diet.

The patients were admitted for a period of 10 days to hospital. Fig. 1 shows the age distribution of the cases. The youngest was 4 months. The majority (50) of the patients were Caucasian. Of the remaining 8, 5 were Negroid, 1 Asian, 1 Anglo-Indian, and 1 Anglo-Jamaican, the latter being the only non-Caucasian having abnormal histology with a classical clinical picture of coeliac disease.

The main clinical features are shown in Table I. The usual symptomatology in the younger patients was failure to thrive or weight loss with abnormal stools and often reduced appetite and vomiting. This complex, or gastrointestinal symptoms alone, was seen in all cases under 3 years of age. In children over 3 years 
TABLE I

Main clinical features

\begin{tabular}{|c|c|c|c|c|c|c|}
\hline & \multicolumn{3}{|c|}{33 patients $<3$ years of age } & \multicolumn{3}{|c|}{25 patients $>3$ years of age } \\
\hline & $\begin{array}{c}\text { Normal } \\
\text { histology } \\
(19)\end{array}$ & $\begin{array}{l}\text { Mucosal } \\
\text { atrophy } \\
\text { (14) }\end{array}$ & Total & $\begin{array}{c}\text { Normal } \\
\text { histology } \\
\text { (12) }\end{array}$ & $\begin{array}{c}\text { Mucosal } \\
\text { atrophy } \\
\text { (13) }\end{array}$ & Total \\
\hline $\begin{array}{l}\text { Failure to thrive or weight loss } \\
\text { Abnormal stools } \\
\text { Abdominal distension } \\
\text { Anorexia } \\
\text { Vomiting }\end{array}$ & $\begin{array}{r}17 \\
8 \\
2 \\
8 \\
8\end{array}$ & $\begin{array}{l}14 \\
13 \\
11 \\
10 \\
11\end{array}$ & $\begin{array}{l}31 \\
21 \\
13 \\
18 \\
19\end{array}$ & $\begin{array}{l}6 \\
3 \\
1 \\
8\end{array}$ & $\begin{array}{l}5 \\
8 \\
6 \\
4\end{array}$ & $\begin{array}{r}11 \\
11 \\
7 \\
12\end{array}$ \\
\hline
\end{tabular}

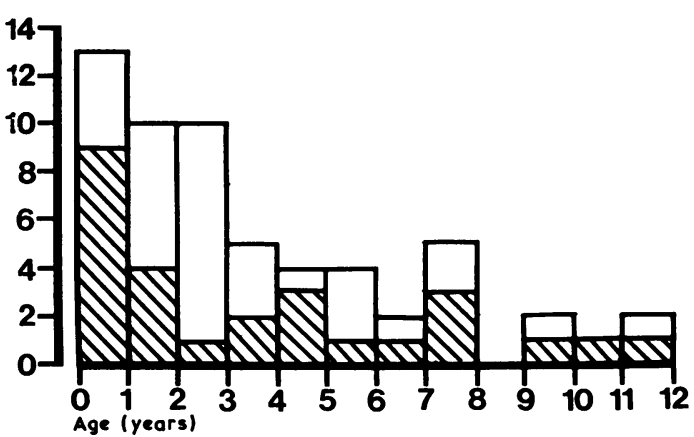

Fig. 1.-Number of patients in each age group (years) at the time of study. Hatched areas indicate patients with mucosal atrophy, the clear areas patients with normal mucosa.

short stature with one or more gastrointestinal disturbances was a frequent indication for investigation, while in others diarrhoea, often with reduced appetite, was the chief symptom. Abdominal distension was recorded in 20 of the 58 cases, being more often seen in the younger children. The low number of symptoms recorded in the older children is explained by the inclusion of 3 asymptomatic patients who had had a normal diet for between 9 months and 2 years as a challenge after an early diagnosis of coeliac disease had been made without biopsy; these all had villous atrophy. Also included are 3 children with a family history of coeliac disease, 2 of whom were short and 1 had diarrhoea. All 3 of these had normal histology. Another patient had dermatitis herpetiformis with normal growth and no gastrointestinal symptoms.

The final diagnosis in the patients in group I with a normal small bowel histology is shown in Table II.

Methods. Standard techniques were used for haematological and biochemical studies (haemoglobin, red cell folate, urea, electrolytes, calcium, phosphate, proteins, alkaline phosphatase, and cholesterol). Stools were examined for pathogens and parasites.

Oral glucose tolerance tests were performed after an

\section{TABLE II}

Final diagnosis in 31 patients with normal small bowel histology (group I)

\begin{tabular}{l|c}
\hline \multicolumn{1}{c|}{ Diagnosis } & No. of patients \\
\hline Emotional deprivation and/or food refusal & 7 \\
Constitutional short stature & 4 \\
Postgastroenteritis & 3 \\
Recurrent respiratory infections & 3 \\
Chronic diarrhoea & 3 \\
Giardiasis & 2 \\
Habitual vomiting & 2 \\
Normal child & 2 \\
Inadequate breast feeding & 1 \\
Iron deficiency with malabsorption & 1 \\
Neurofibromatosis & 1 \\
Dermatitis herpetiformis & 1 \\
Eczema & 1 \\
\end{tabular}

overnight fast, a dose of $1 \mathrm{~g} / \mathrm{kg}$ glucose being given. Capillary samples for blood glucose estimation were taken at 30-minute intervals for $2 \frac{1}{2}$ hours. A maximum rise in excess of $40 \mathrm{mg} / \mathrm{dl}$ was considered normal. Faecal fat excretion was determined over a 3-day period by the method of van de Kamer, ten Bokkel Huinink, and Weyers (1949). The children were given a normal ward diet and the stools were collected between carmine markers. The upper limit of normal was taken as 4.5 fat/day (Anderson, 1966). Difficulty in obtaining a complete urine collection was encountered frequently when determining $D$-xylose excretion (Hubble and Littlejohn, 1963). Eight results were excluded because of a very low urine volume $(<1 \mathrm{ml} / \mathrm{kg}$ body weight per h). A 5-hour urine excretion of more than $20 \%$ of the $5 \mathrm{~g}$ dose was regarded as normal.

The radiological criteria described by Laws et al. (1963) and Laws and Neale (1966) were used to diagnose malabsorption and hypolactasia. A mixture of Micropaque ( $1: 2$ dilution) with $25 \mathrm{~g}$ lactose in $180 \mathrm{ml}$ of fluid was used. The patients were given between 90 and $150 \mathrm{ml}$ according to age, and a single supine film was taken between 45 and 60 minutes. An additional erect film was taken in some cases. Bone age was assessed using the criteria of Greulich and Pyle.

In the search for another test for fat absorption, and a 
possible screening test for coeliac disease, a method was devised using Prosparol (Duncan, Flockhart; arachis oil $50 \%$ in water) as an oral fat load. The patients were given a dose of $1.5 \mathrm{~g} / \mathrm{kg}$ after an overnight fast and 20 minutes after a dose of metoclopramide. Venous blood samples $(2 \mathrm{ml})$ for triglyceride estimation were taken initially, and at 2 and 4 hours after the load.

Intestinal biopsy specimens were obtained using the Watson paediatric biopsy capsule (Read et al., 1962) which was positioned radiographically just distal to the ligament of Treitz. Tissue obtained was examined for villous morphology using a dissecting microscope (Walker-Smith, 1967) and well orientated sections were later examined under the light microscope. Specimens with short broad villi and cuboidal epithelial cells with some increase in the inflammatory cells of the lamina propria were considered to show partial villous atrophy, while those with absence of villi, deep crypts, cuboidal epithelial cells, and extensive cellular infiltration of the lamina propria were regarded as subtotal villous atrophy (Shiner and Doniach, 1960).

\section{Results}

Not all investigations were successfully performed in all the children.

Glucose tolerance tests (Fig. 2). Of those patients with an abnormal mucosal histology a rise in blood glucose of less than $40 \mathrm{mg} / \mathrm{dl}$ was found in $\mathbf{1 5}$ of the 22 patients studied, and was less than $50 \mathrm{mg} / \mathrm{dl}$ in the remaining 7 . Rises of less than this were seen in more than $50 \%$ of cases with normal histology.

Faecal fat (Fig. 2). Faecal fat excretion in excess of $4.5 \mathrm{~g}$ /day was found in 10 of 18 patients with abnormal histology. Of the 8 in whom steatorrhoea was not shown, 5 were over 3 years of age and 3 under 3 years. There was one case, a West Indian child, with a high faecal fat excretion $(5.5 \mathrm{~g} / \mathrm{d})$ and a normal histology, whose malabsorption was thought to be secondary to iron deficiency anaemia and who responded clinically to treatment with iron.

D-xylose excretion (Fig. 2). A xylose excretion of less than $20 \%$ was recorded in more than $50 \%$ of cases in both groups. However, a normal excretion was found in 6 of 14 cases with abnormal histology.

Radiology of small bowel. Barium lactose examination showed a malabsorption pattern, and in some cases hypolactasia as well, in 13 out of 16 patients with abnormal histology. Of the 3 with normal studies, 2 had partial villous atrophy. 26 cases with normal histology had barium studies and

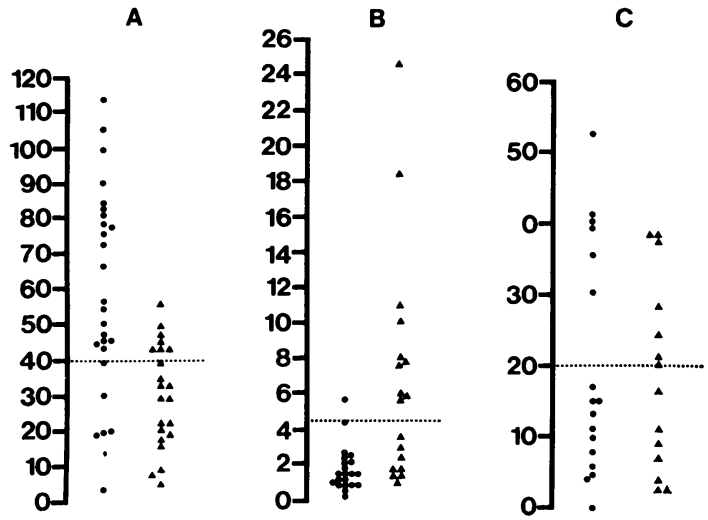

FIG. 2.-( $A$ ) Maximum rise of blood glucose ( $\mathrm{mg} / \mathrm{dl}$ ) in oral glucose tolerance test. (B) 3-day faecal fat excretion $(g / 24 h)$. (C) Oral D-xylose excretion expressed as a percentage of oral load excreted in 5 hours, in patients with normal intestinal histology $\bigcirc$, and with mucosal atrophy $\mathbf{\Delta}$.

in 7 the study was abnormal. However, in 6 of these the study was regarded as borderline, and the 7 th was the child with iron deficiency and steatorrhoea.

Radiological assessment of bone age. In those patients with villous atrophy 14 out of 20 examined had a bone age more than $10 \%$ below the chronological age, while 13 out of 29 with a normal histology had a reduced bone age. Of the 6 with villous atrophy and a normal bone age 5 were under 2 years of age.

Haematology and biochemistry (Fig. 3). More than half of the patients with villous atrophy had a haemoglobin level of less than $11.5 \mathrm{~g}$ as against $25 \%$ of those with normal histology. There was a wide scatter of values for red cell folate in both groups. However, of those with villous atrophy, 9 out of 14 had levels below 120 $\mathrm{ng} / \mathrm{ml}$ while 4 out of 19 had similarly low levels in the group with normal histology.

Only 2 of 27 patients with normal histology had serum albumin levels of less than $3.5 \mathrm{~g} / 100 \mathrm{ml}$, while 9 out of 24 with villous atrophy had low levels.

Prosparol tolerance test. Of 14 patients with villous atrophy, $8 \mathrm{had}$ a rise of triglycerides of less than $50 \mathrm{mg} / 100 \mathrm{ml}$, while 8 out of 15 children with normal histology had similar low rises.

\section{Discussion}

Oral glucose tolerance has long been known to be influenced by factors other than mucosal absorption 
A

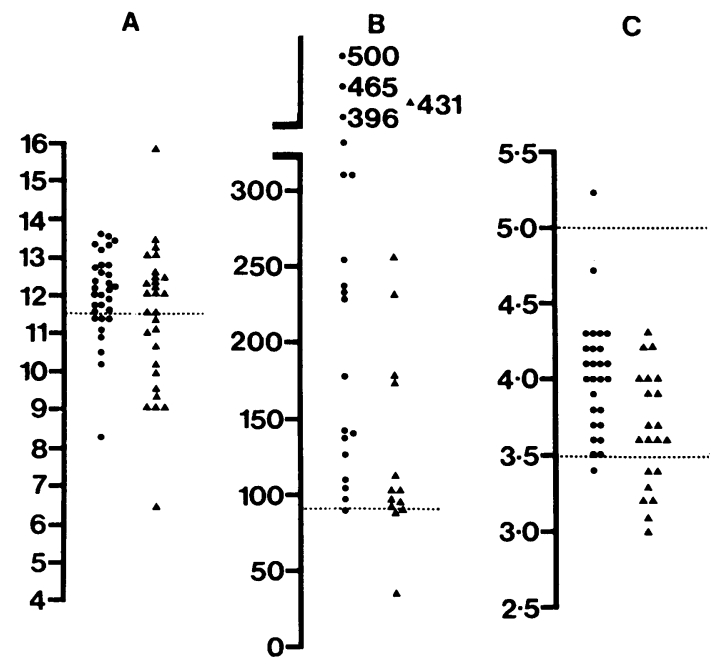

a rise in glucose of less than $40 \mathrm{mg} / \mathrm{dl}$ in 38 out of 40 children with coeliac disease (Table III), and a maximum rise greater than $50 \mathrm{mg} / \mathrm{dl}$ appears to exclude mucosal damage in our series.

It may be that incomplete collection of stools contributed to the high proportion of our children with coeliac disease in whom there was no demonstrable steatorrhoea (8 out of 18). A low fat intake due to anorexia and vomiting was also a factor in some cases. However, McNicholl and Egan (1968) recorded a low fat output in 14 of 43 coeliac children given a controlled and moderate fat intake. If it is accepted that up to $30 \%$ of cases of coeliac disease do not have increased fat excretion (Egan-Mitchell and McNicholl, 1972), it is probable that only a few more cases in our series would have been identified with a better controlled method. Even with a simple stool collection such as we report, inpatient and laboratory staff time spent is considerable and the dividend is certainly poor.

The D-xylose excretion test is limited in infants and small children by the difficulty of collecting a 5-hour urine sample and this may account for a low excretion in many cases in both groups in our series. However, we found that 6 out of 14 cases with villous atrophy had a normal excretion and other workers (Visakorpi et al., 1970; Hamilton et al., 1969; Table III) have recorded similar results. The proportion of our cases with villous atrophy and a high excretion might have been

TABLE III

Summary of results and comparison with other studies in children with coeliac disease

\begin{tabular}{|c|c|c|c|c|c|c|c|}
\hline & Prese & eries & & & Reported series & & \\
\hline Investigation & $\begin{array}{c}\text { Normal } \\
\text { histology }\end{array}$ & $\begin{array}{l}\text { Mucosal } \\
\text { atrophy }\end{array}$ & $\begin{array}{l}\text { Hamilton et al. } \\
\text { (1969) Toronto }\end{array}$ & $\begin{array}{l}\text { Visakorpi et al. } \\
\text { (1970) Finland }\end{array}$ & $\begin{array}{c}\text { McNicholl and } \\
\text { Egan (1968) } \\
\text { Galway }\end{array}$ & $\begin{array}{c}\text { Cameron et al. } \\
\text { (1962) } \\
\text { Birmingham }\end{array}$ & $\begin{array}{l}\text { McNeish and } \\
\text { Willoughby } \\
\text { (1969) Glasgow }\end{array}$ \\
\hline $\begin{array}{l}\text { Glucose tolerance } \\
\text { rise } \\
<40 \mathrm{mg} / 100 \mathrm{ml} \\
\text { Faecal fat } \\
>4.5 \mathrm{~g} / \text { day } \\
\\
\text { D-xylose }<20 \% \\
\text { Barium meal } \\
\text { abnormal } \\
\text { Bone age reduced } \\
\text { Red cell folate } \\
<90 \mathrm{ng} / \mathrm{ml}\end{array}$ & $\begin{array}{r}7 / 27 \\
1 / 21 \\
11 / 17 \\
7 / 26 \\
13 / 29 \\
0 / 19 \\
\\
8 / 31 \\
1 / 27\end{array}$ & $\begin{array}{r}15 / 22 \\
10 / 18 \\
8 / 14 \\
13 / 16 \\
14 / 20 \\
3 / 14 \\
14 / 26 \\
9 / 24\end{array}$ & $\begin{array}{c}26 / 32 \\
\text { (not lactose) } \\
\\
34 / 42\end{array}$ & $\begin{array}{c}18 / 22 \\
(>5 \mathrm{~g} / \mathrm{d}) \\
11 / 21 \\
15 / 16 \\
\text { (not lactose) } \\
11 / 11 \\
\\
\\
19 / 22 \\
(11 \mathrm{~g})\end{array}$ & $\left(\begin{array}{c}29 / 43 \\
=3 \cdot 5 \mathrm{~g} / \mathrm{d})\end{array}\right.$ & $\begin{array}{c}9 / 19 \\
\\
26 / 31 \\
\text { (not lactose) }\end{array}$ & $\begin{array}{c}30 / 30 \\
\text { (whole blood) } \\
\text { folate } 50 \\
\mathrm{ng} / \mathrm{ml} \text { ) }\end{array}$ \\
\hline
\end{tabular}


reduced by giving gluten on the evening before the test, but even so the investigation must be regarded as technically unsuitable for young patients. Its value in adults has also been questioned again recently (Sladen and Kumar, 1973).

Radiological examination of the small bowel with barium lactose as a screening test for malabsorption seems to be more valuable in our hands than the absorption tests. Other workers have used barium alone and recorded similar results (Table III), obtaining over $80 \%$ positive examinations in coeliac disease, while Carswell and Ferguson (1972) found $77 \%$ positive results in 30 coeliacs and $25 \%$ positive results in 22 noncoeliacs.

On the other hand, the use of folate levels, though at first promising when $\mathrm{McNeish}$ and Willoughby (1969) recorded clear-cut identification of coeliacs with whole blood folate levels below $50 \mathrm{ng} / \mathrm{ml}$, has since been disappointing and Carswell and Ferguson found levels below $60 \mathrm{ng} / \mathrm{ml}$ in $67 \%$ of coeliacs and $42 \%$ of noncoeliacs. Likewise, in our series red cell folate has been of little help.

The Prosparol tolerance test, in common with any using an oral load, is subject to the uncertainty of gastric emptying time and probably also to variations in gut transit time affecting absorption. Metoclopramide undoubtedly hastens gastric emptying time but does not guarantee complete emptying. Prosparol is rather unpalatable and was unforunately taken very reluctantly by the majority of patients, particularly the younger ones. This problem alone suggests that the test is unlikely to prove useful even if a clear identification of the coeliac patients had been shown.

If the results of the more useful tests (barium lactose, glucose tolerance, and faecal fat excretion) are considered together, only $50 \%$ of the patients with villous atrophy are identified by the best of the combinations shown in Table IV. The majority of the patients with normal histology, however, appear to have had coeliac disease correctly excluded. Thus, if the three tests had been used a a combined screening method, biopsy could have been avoided in 20 cases, but 7 out of 11 children with abnormal mucosa would not have been diagnosed.

It appears from this study that the application of a large number of tests to show malabsorption in children suspected of having coeliac disease is unrewarding. This is partly because of the inaccuracy of some of the tests, particularly when used in children, but also because, as emphasized by Anderson et al. (1972), there are a small number of patients with villous atrophy in whom malabsorp-
TABLE IV

Combined results for those patients who had multiple tests

\begin{tabular}{|c|c|c|}
\hline Investigations & $\begin{array}{c}\text { Normal } \\
\text { histology }\end{array}$ & $\begin{array}{l}\text { Mucosal } \\
\text { atrophy }\end{array}$ \\
\hline $\begin{array}{l}\text { Glucose tolerance }<40 \mathrm{mg} / \mathrm{dl} \text { rise } \\
\text { Barium lactose positive }\end{array}$ & $0 / 25$ & $7 / 14$ \\
\hline $\begin{array}{l}\text { Glucose tolerance }<40 \mathrm{mg} / \mathrm{dl} \text { rise } \\
\text { Faecal fat }>3.5 \mathrm{~g} / \mathrm{d}\end{array}$ & $0 / 20$ & $8 / 18$ \\
\hline $\begin{array}{l}\text { Barium lactose positive } \\
\text { Faecal fat }>3.5 \mathrm{~g} / \mathrm{d}\end{array}$ & $1 / 21$ & $6 / 12$ \\
\hline $\begin{array}{l}\text { Glucose tolerance }<40 \mathrm{mg} / \mathrm{dl} \text { rise } \\
\text { Barium lactose positive } \\
\text { Faecal fat }>3.5 \mathrm{~g} / \mathrm{d}\end{array}$ & $0 / 20$ & $4 / 11$ \\
\hline
\end{tabular}

tion is not demonstrable. Of the tests we report, the radiological examination of the small bowel seems to be the only one which could reasonably be used as a screening test for coeliac disease. It does, however, give many $(25 \%)$ false positive results, as do most of the more recently described tests, such as IgA levels (Carswell and Ferguson, 1972) and reticulin antibodies (Seah et al. 1971; Von Essen, Savilahti, and Pelkonen, 1972). Food antibodies (Carswell and Ferguson, 1972) and the one-hour blood xylose test seem more promising but are not infallible (Rolles et al., 1974).

No investigation other than small intestinal biopsy had been shown to detect with certainty the patients with mucosal atrophy and possible gluten enteropathy. In spite of fears of a significant morbidity, and indeed mortality from this procedure in children (Sheldon and Tempany, 1966), small bowel biopsy has now been shown to carry an extremely low incidence of complications (Townley and Barnes, 1973); in our series there were no complications and with adequate sedation, the procedure was not distressing for the child. Intestinal biopsy is certainly less likely to give misleading results than any of the other investigations available. We have abandoned the use of tests of intestinal absorption as 'screening tests' and undertake intestinal biopsy as a primary investigation in suspected coeliac disease.

Valuable technical assistance provided by Miss J. I. Silks and Mr. A. J. Langmead is gratefully acknowledged. The study would not have been possible without the co-operation of nursing staff and many colleagues in the Departments of Pathology and Radiology. 


\section{REFERENCES}

Anderson, C. M. (1966). Intestinal malabsorption in childhood. Archives of Disease in Childhood, 41, 571.

Anderson, C. M., Gracey, M., and Burke, V. (1972). Coeliac disease; some still controversial aspects. Archives of Disease in Childhood, 47, 292.

Cameron, A. H., Astley, R., Hallowell, M., Rawson, A. B., Miller, C. G., French, J. M., and Hubble, D. V. (1962). Duodenojejunal biopsy in the investigation of children with coeliac disease. Quarterly fournal of Medicine, 31, 125.

Carswell, F., and Ferguson, A. (1972). Food antibodies in seruma screening test for coeliac disease. Archives of Disease in Childhood, 47. 594.

Egan-Mitchell, B., and McNicholl, B. (1972). Constipation in childhood coeliac disease. Archives of Disease in Childhood, 47, 238.

Hamilton, J. R., Lynch, M. J., and Reilly, B. J. (1969). Active coeliac disease in childhood. Quarterly fournal of Medicine, 38, 135.

Hubble, D., and Littlejohn, S. (1963). The D-xylose excretion test in coeliac disease in childhood. Archives of Disease in Childhood, 38, 476.

Laws, J. W., and Neale, G. (1966). Radiological diagnosis of disaccharidase deficiency. Lancet, 2, 139.

Laws, J. W., Shawdon, H., Booth, C. C., and Stewart J. S. (1963). Correlation of radiological and histological findings in idiopathic steatorrhoea. British Medical fournal, 1, 1311.

McNeish, A. S., and Willoughby, M. L. N. (1969). Whole-blood folate as a screening test for coeliac disease in childhood. Lancet, 1, 442.

McNicholl, B., and Egan, B. (1968). Jejunal biopsy in coeliac disease. Clinical Paediatrics, 7, 544.
Read, A. E., Gough, K. R., Bones, J. A., and McCarthy, C. F. (1962). An improvement to the Crosby peroral intestinal biopsy capsule. Lancet, $1,894$.

Rolles, C. J., Kyaw Myint, T. O., Wai-Kee Sin, and Anderson, C. M. (1974). Family study of coeliac disease. Gut, 15, 827.

Seah, P. P., Fry, L., Rossiter, M. A., Hoffbrand, A. V., and Holborow, E. J. (1971). Antireticulin antibodies in childhood coeliac disease. Lancet, $2,681$.

Sheldon, W., and Tempany, E. (1966). Small intestinal peroral biopsy in coeliac children. Gut, 7, 481

Shiner, M., and Doniach, I. (1960). Histopathologic studies in steatorrhoea. Gastroenterology, 38, 419.

Sladen, G. E., and Kumar, P. J. (1973). Is the xylose test still a worthwhile investigation? British Medical fournal, 3, 223.

Test, C. E., Nichols, R. L., Landau, R. L., Ricketts, H. T., and Loughead, R. (1956). American Fournal of the Medical Sciences, 231, 69.

Townley, R. R. W., and Barnes, G. L., (1973). Intestinal biopsy in childhood. Archives of Disease in Childhood, 48, 480.

van de Kamer, J. H., ten Bokkel Huinink, H., and Weyers, H. A. (1949). Rapid method for the determination of fat in feces. fournal of Biological Chemistry, 177, 347.

Visakorpi, J. K., Kuitunen, P., and Pelkonen, P. (1970). Intestinal malabsorption: a clinical study of 22 children over two years of age. Acta Paediatrica Scandinavica, 59, 273.

Von Essen, R., Savilahti, E., and Pelkonen, P. (1972). Reticulin antibody in children with malabsorption. Lancet, 1, 1157.

Walker-Smith, J. (1967). Dissecting microscope appearance of small bowel mucosa in children. Archives of Disease in Childhood, 42, 626.

Correspondence to Dr. A. P. Mowat, Department of Child Health, King's College Hospital, London SE5. 